to propionic acid ( 2 moles) and acetic acid ( 1 mole). In the absence of a detailed mechanism, this reaction may be regarded as a summary of the overall process postulated here.

The acetate formed under the anaerobic conditions of our experiments is likely to be produced from pyruvate by hydrolytic fission into acetate and formate rather than by the oxidative decarboxylation characteristic of aerobic tissues.

These ideas are summarized in the following scheme:

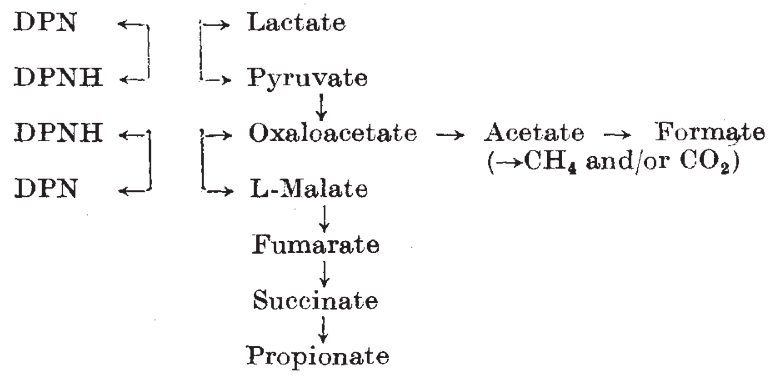

(the late) A. John G. Barnett M. G. C. M. Dow

Division of Agricultural Biochemistry,

Department of Biological Chemistry,

University of Aberdeen.

June 28.

${ }^{1}$ Hershberger, T. V., Bentley, O. G., Cline, J. H., and Tyznik, W., J. Agric. and Food Chern., 4, 952 (1956).

${ }_{2}$ Barnett, A. J. G., and Reid, R. I., J. Agric. Sci, 48, 315 (1957).

${ }^{3}$ Burroughs, W., Frank, N. A., Gerlaugh, P., and Bethke, R. M. J. Nutr., 40,9 9 (1950)

4James, A. T., and Martin, A. J. P., Biochem. J., 50, 679 (1954).

s Johns, A. T., J. Gen. Microbiol., 5, 326, 337 (1951).

'Wood, H. G., Physiol. Revs., 26, 198 (1946).

" Kornberg, H. L., and Irebs, H. A., Nature, 179, 988 (1957).

s Singer, T. P., Massey, V., and Kearney, E. B., Biochim. Bioxhys. Acta, 19, $200(1956)$.

- Fitz, A., Ber. deutsch. chem. Ges., 13, 1309 (1880).

10 von Freadenreich, E., and Orla Jensen, S., Zbl. Bukt., II, 17, 529 (1907).

\section{Accumulation of a Stable Phosphorus Compound in Glycolysing Insect Muscle}

IN isolated metathoraxes of the cockroach Periplaneta americana, 85 per cent of the mass of which is formed by the thoracic muscles, changes in various fractions of acid-soluble phosphorus compounds were followed during exposure of the preparations to anoxia. It was found that in such conditions there is a rapid breakdown of the labile phosphorus com. pounds, namely, arginine phosphate and adenosine triphosphate ${ }^{1}$. At the same time, however, the level of inorganic phosphate did not increase significantly ; on the contrary, in many cases it showed a tendency to decrease. As the total acid-soluble phosphorus did not change at all, these facts indicated an accumu. lation of some stable phosphorus compound during anaerobiosis : this compound was found to be stable even to prolonged acid hydrolysis (three hours in normal acid).

To obtain some information about the nature of this compound, the trichloracetic acid extract of the muscles was subjected to fractionation by means of the salts of alkaline earth metals ${ }^{2}$. For this purpose six hemi-metathoraxes weighing about $0.6 \mathrm{gm}$. were combined, the symmetrical halves serving as control. The stable ester formed in anaerobiosis was found quantitatively in the barium soluble-alcohol insol-
Table 1. Stable Phosphate Ester in Cockroach Metathoraxe

\begin{tabular}{|c|c|c|c|}
\hline \multicolumn{3}{|c|}{$\begin{array}{l}\text { Phosphorus split off by periodic acid } \\
\text { treatment (mgm. per } 100 \mathrm{gm} .)\end{array}$} & \multirow{2}{*}{$\begin{array}{l}\text { Glycerol equivalent to } \\
\text { the increase in phos- } \\
\text { phorus } \\
\text { (mgm. per } 100 \mathrm{gm} . \text { ) }\end{array}$} \\
\hline Aerobic & $\begin{array}{l}\text { After } 40 \text { min. } \\
\text { anaerobiosis }\end{array}$ & $\begin{array}{c}\text { Increase during } \\
\text { anaerobiosis }\end{array}$ & \\
\hline $\begin{array}{r}5 \\
13 \\
20 \\
9\end{array}$ & $\begin{array}{l}36 \\
55 \\
52 \\
32 \cdot 5\end{array}$ & $\begin{array}{l}31 \\
42 \\
32 \\
23 \cdot 5\end{array}$ & $\begin{array}{r}92 \\
124 \\
95 \\
70\end{array}$ \\
\hline
\end{tabular}

uble fraction. Its phosphate could not be split off by heating in normal alkali hydroxide for three hours; it was, however, liberated readily by subsequent heating with periodic acid in normal sulphuric acid. Thus the compound accumulated during anaerobiosis is most probably glycerophosphoric acid. The amount of phosphate split off by periodic acid treatment and the calculated amount of glycerophosphate, expressed as glycerol, are given in Table 1.

The formation of glycerophosphate in insect muscle during glycolysis is quite possible, as the activity of $\alpha$-glycerophosphate dehydrogenase was found to be very high in this tissue ${ }^{3}$. In parallel experiments, during the same period of anaerobiosis, glycogen breakdown was found to be equivalent to $250 \pm 33 \mathrm{mgm}$. per cent glucose in these prepara. tions; thus glycerophosphate would constitute a considerable proportion of the breakdown products, which would explain low yields of lactic acid in glycolysing insect muscle. As glycerophosphate would be most probably formed by triosephosphate dismutation, the occurrence of pyruvate among the products of insect glycolysis ${ }^{5}$ would also be explained.

Zoological Institute, VÁCLAV KUBIŠTA

Charles University, Prague. April 10.

${ }^{1}$ Kubista, V., Acta soc. zool. Bohemoslov., 21, 126 (1957).

'Sacks, J., J. Biol. Chem., 181, 655 (1949).

${ }^{3}$ Zebe, E., Experientia, 12, 68 (1956).

${ }^{4}$ Barron, E. S. G., and Tahmisian, T. N., J. Cell. Comp. Physial. 32,57 (1948).

'Humphrey, G. F., J. Cell. Comp. Physiol., 34, 323 (1949).

\section{Isolation of 2-Aminoethanesulphinic Acid from a Mollusc}

PAPER chromatographic analyses of extracts from Septifer (Mytilisepta) virgatus (Wiegmann) by means of the iodine-azide reaction ${ }^{1}$ showed the presence of an unusual sulphur compound, leading to its isolation. The isolate was identified as 2 -aminoethanesulphinic acid. In 1951 Bergeret and Chatagner ${ }^{2}$ observed paper chromatographically that this compound was formed from cysteinesulphinic acid by the action of liver acetone powder. Furthermore, in 1953, Awapara and Wingo ${ }^{3}$ isolated ${ }^{35} \mathrm{~S}-2$-aminoethanesulphinic acid and ${ }^{35} \mathrm{~S}$-taurine from rat liver after injection of ${ }^{35}$ S-cysteine. 2-Aminoethanesulphinic acid, however, has never been reported to be isolated directly from organisms under natural conditions without administration of the precursors such as cysteinesulphinic acid, cysteine or cystine. We have found that every tissue of this Septifer contains this compound in considerable quantity.

Shells of the Septifer were removed and the contents were ground in a mixer with water. The extract was deproteinized with ethanol, centrifuged, the precip. 